\title{
The Association of HLA Class 1 and Class 2 Antigens with Multiple Myeloma in Iranian Patients
}

\section{Iranlı Multipl Miyelom Hastalarinda HLA Sinif 1 ve Sinff 2 Antijenlerinin Birlikteliği}

\author{
Arezou Sayad1, Mohammad Taghi Akbari², Mahshid Mehdizadeh3,4, Elham Roshandel ${ }^{3}$, \\ Soheila Abedinpour ${ }^{3}$, Abbas Hajifathali ${ }^{3}$ \\ 1Shahid Beheshti University of Medical Sciences, Department of Medical Genetics, Tehran, Iran \\ ${ }^{2}$ Tarbiat Modares University Faculty of Medical Science, Department of Medical Genetics, Tehran, Iran \\ 3 Shahid Beheshti University of Medical Sciences, Taleghani Bone Marrow Transplantation Center, Tehran, Iran \\ 4Shahid Beheshti University of Medical Sciences, Pediatric Congenital Hematologic Disorders Research Center, Tehran, Iran
}

\begin{abstract}
:
Objective: Multiple myeloma (MM) is a B-cell malignancy characterized by the clonal proliferation of malignant plasma cells. According to results of some studies, it has been suggested that the HLA class 1 and 2 genes have susceptibility effects on MM. Studies of different populations have reported different HLA class 1 and 2 alleles that affect MM. In this study, we assessed the association of HLA class 1 and class 2 antigens with MM in Iranian patients.

Materials and Methods: We performed a case-control genotyping study with 105 Iranian MM patients that were selected from the bone marrow transplantation department of Taleghani Hospital and 150 controls using single specific primerpolymerase chain reaction with the HLA-Ready Gene ABDR Kit.

Results: Our results demonstrated that $21 \%$ of patients versus $12 \%$ of controls and $11 \%$ of patients versus $3 \%$ of controls carried HLA-A ${ }^{*} 03$ and HLA-B ${ }^{*} 18$, respectively. The MM patients had a significant increase in the frequency of HLA-A $A^{*} 03$ and HLA-B*18 alleles in comparison to control subjects $(\mathrm{p}=0.039, \mathrm{OR}=2.057$ and $\mathrm{p}=0.013, \mathrm{OR}=3.567$, respectively).

Conclusion: Our findings suggested that the HLA-A ${ }^{*} 03$ and HLA-B* 18 alleles have significant susceptibility effects on MM in the Iranian population. However, compared to other populations, the above-mentioned alleles had different statuses. Since there are not many studies evaluating and calculating this association among ethnic groups, further studies among other populations are needed to explain the exact association of the HLA genes with MM.
\end{abstract}

Key Words: Multiple myeloma, HLA-A, HLA-B, HLA-DRB1, Genetic susceptibility

Özet:

Amaç: Multiple myeloma (MM), malign plazma hürelerinin klonal çoğalması ile karakterize bir B hücre neoplazisidir. Çeşitli çalışmaların sonuçlarına göre, bazı sınıf 1 ve 2 HLA genlerinin hastalığa yatkınlık sağladığına dair görüşler ortaya atılmıştır.

Address for Correspondence: Abbas HAJIFATHALI, M.D.,

Shahid Beheshti University of Medical Sciences, Taleghani Bone Marrow Transplantation Center, Tehran, Iran

E-mail: ar.sayad@yahoo.com

Received/Geliş tarihi : March 17, 2013

Accepted/Kabul tarihi : June 10, 2013 
Farklı popülasyonlarda yapılan çalışmalarda, farklı HLA sınıf 1 ve 2 allellerinin MM üzerine etkisi olduğu bildirilmiştir. Bu çalışmada, İranlı MM hastalarında HLA sınıf 1 ve sınıf 2 antijenlerinin birlikteliğini değerlendirdik.

Gereç ve Yöntemler: HLA-Ready Gene ABDR kitleriyle tekli spesifik primer polimeraz zincir reaksiyonu yönteminin kullanıldığı bu olgu-kontrol genetiplendirme çalışmasında, hasta grubuna Taleghani Hastanesi kemik iliği nakli bölümünden seçilen 105 İranlı MM hastası ve 150 de kontrol olgusu dahil edilmiştir.

Bulgular: Çalışma sonucunda, HLA-A*03 hasta grubunda \%21 ve kontrol grubunda \%12 bulunurken, HLA-B* 18 ise hasta grubunda $\% 11$ ve kontrol grubunda $\% 3$ olarak saptanmıştır. MM hastalarının HLA-A*03 ve HLA-B* 18 allele sahip olma oranı kontrol olgularıyla karşılaştırıldığında istatistiki olarak anlamlı olacak şekilde yüksek bulunmuştur ( $p=0,039$, OR=2,057 ve $\mathrm{p}=0,013, \mathrm{OR}=3,567$, sırasiyla).

Sonuç: Bizim bulgularımız, İran toplumunda HLA-A*03 ve HLA-B* 18 allel varlığının istatistiki olarak anlamlı olacak şekilde MM'ye yatkınlık yarattığını ortaya koymaktadır. Bununla birlikte, diğer toplumlara bakıldığında adı geçen allellerin aynı sonucu doğurmadıkları görülmektedir. Farklı etnik gruplar arasındaki bu birlikteliği değerlendiren fazla sayıda çalışma olmadığı için, gelecek dönemlerde MM'li hastalarda HLA genlerinin birlikteliğinin sonuçlarını izah edebilecek daha ayrıntılı çalışmalara gereksinim vardır.

Anahtar Sözcükler: Multipl miyelom, HLA-A, HLA-B, HLA-DRB1, Genetik yatkınlık

\section{Introduction}

Multiple myeloma (MM) is a B-cell malignancy characterized by the clonal proliferation of malignant plasma cells, and evidence indicates that the bone marrow microenvironments of tumor cells have a crucial role in myeloma pathogenesis [1]. Neurological and impaired hemopoiesis symptoms, bone complications, renal failure, and infection are some of the heterogeneous clinical features [2]. MM is the second most prevalent blood cancer after nonHodgkin lymphoma [3]. MM represents approximately $1 \%$ of all cancers, $2 \%$ of all cancer deaths, and $10 \%$ of hematological malignancies. The prevalence of MM varies among different populations. Blacks have a 2-fold higher incidence than whites, while the Japanese, Chinese, and South Koreans have the lowest incidence [4,5]. Although the exact etiology of $\mathrm{MM}$ is unknown, the genetic factor has an important effect on it. Simply, MM is a condition characterized by the unlimited proliferation of plasma cells. Since the HLA genes are associated with a variety of immunologic diseases, they may be involved as a crucial factor in MM [6]. In 1970 for the first time, after recognition of HLA class 1 and prior to identification of HLA class 2, the susceptibility effects of HLA genes on MM were studied $[7,8,9,10,11,12]$. Not many studies have taken sufficient account of the effect of HLA genes on the susceptibility to MM in different populations. These studies reported different susceptible or protective alleles of HLA genes in association with MM. Some studies indicated no significant association between HLA-A and -B genes and MM, while other studies demonstrated that HLA-A3, -B18, -Bw65, and -DRw14 had associations with MM $[13,14,15]$. In the present study, for the first time, the associations of HLA class 1 and 2 genes with MM in Iranian patients were investigated.

\section{Materials and Methods}

\section{Patients and Controls}

One hundred and five Iranian patients were selected from the bone marrow transplantation department of Taleghani Hospital. The diagnosis of MM was made by an oncologist. Additionally, one hundred and twenty ethnically, age-, and sex-matched healthy individuals without personal or familial history of cancer or autoimmune disorders were included as controls. The subjects gave informed consent to participate.

\section{DNA Extraction and HLA Genotyping}

Genomic DNA from venous peripheral blood samples was extracted by the salting-out method [16]. HLA typing was performed at the Tehran Medical Genetics Laboratory. HLA-A, $-B$, and -DRB1 genotyping was carried out based on lowresolution single specific primer-polymerase chain reaction (SSP-PCR) HLA typing with the HLA-Ready Gene ABDR Kit (Inno-Train Diagnostik GmbH, Germany) according to the manufacturer's recommendation. The PCR products were run on $2 \%$ agarose gel.

\section{Statistical Analysis}

By using chi-square and Fisher exact tests, comparisons between HLA-A, -B, and -DRB1 alleles of MM patients and the controls were performed. SPSS 18.0 for Windows was used for analysis and $\mathrm{p}<0.05$ was considered to be statistically significant. The p-value was corrected with Bonferroni correction. In statistics, the Bonferroni correction is a method used to counteract the problem of multiple comparisons. Odds ratio (OR) and 95\% confidence interval (CI) were determined.

\section{Results}

Distributions of sex and age of MM patients and the controls are shown in Table 1. The allele frequencies of HLA-A, -B, and 
-DRB1 in MM patients and controls are demonstrated in Table 2. As outlined in Table 2, no significant associations between HLA-DRB1 and MM were observed. Low-resolution HLA typing revealed that $21 \%$ of patients versus $12 \%$ of controls and $11 \%$ of patients versus $3 \%$ of controls carried HLA-A*03 and HLA-B* 18 , respectively. The MM group had a significant increase in the frequency of HLA-A* 03 and HLA-B* 18 alleles in comparison to control subjects $(\mathrm{p}=0.039, \mathrm{OR}=2.057$ and $\mathrm{p}=0.013, \mathrm{OR}=3.567$, respectively) (Table 2 ).

\section{Discussion}

After description of a serological technique for HLA typing, studies on the association of the HLA genes with susceptibility to or protection against different disease were begun. In our research, for the first time, we investigated the association of HLA class 1 and 2 genes with MM disease in Iranian patients. In our study, the HLA-A*03 and HLA-B* 18 alleles had higher frequencies in $\mathrm{MM}$ patients than in control individuals and had significantly positive associations with MM. Therefore, the HLA-A ${ }^{*} 03$ and HLA-B* 18 alleles have a susceptibility effect in Iranian $\mathrm{MM}$ patients $(\mathrm{p}=0.039$ and $\mathrm{OR}=2.057, \mathrm{p}=0.013$ and $\mathrm{OR}=3.567$, respectively).

Consistent with our results, in 2002, a study on $68 \mathrm{MM}$ patients in southern Africa reported that the HLA-B* 18 allele had an association $(\mathrm{p}<0.005, \mathrm{OR}=6.3)$ and HLA-DRB1 had no association with MM significantly. In contrast to our results, however, that study found that there was no statistically significant association between HLA-B and MM [14]. Patel et al. demonstrated no significant association between antigens

Table 1. Distributions of sex and age of multiple myelom (MM) patient and control groups.

\begin{tabular}{|l|l|l|}
\hline Variables & MM patients & Controls \\
\hline Female [no. (\%)] & $47(45)$ & $69(46)$ \\
\hline $\begin{array}{l}\text { Male [no. (\%)] } \\
\begin{array}{l}\text { Mean age } \pm \text { SD, age } \\
\text { range (years) }\end{array}\end{array}$ & $58(55)$ & $81(54)$ \\
\hline
\end{tabular}

at either the A or the B locus in MM patients compared to controls [15]. Additionally, in a study on black and white men in 1992, it was shown that black MM patients had significantly higher HLA-Bw65 and HLA-DRw14 allele frequencies than black controls, while white MM patients had a higher A3 allele frequency than white controls [13]. A study on German, Dutch, American, and English subjects showed a weak association between HLA-B5 and MM $[8,9,10,17]$. No significant HLA-A and -B allele associations were demonstrated in French and Swiss MM patients, although the MM patients from another area of France showed a negative association between HLAAw32 and MM [6,7,12]. Ludwig and Mayr, in 1982, reported that comparisons between all available studies showed a significantly increased frequency of HLA-B5 [18].

HLA allele associations in our population demonstrated some differences from previous published studies on MM. Variations among ethnic groups may support these differences. Not many studies have taken sufficient account of the association between HLA and MM. Moreover, there are not many studies that have evaluated and calculated this association among ethnic groups. It is suggested that other populations be studied to find the correlation of HLA and MM to find out the exact association.

\section{Conclusion}

The HLA-A*03 and HLA-B*18 alleles have significant susceptibility effects on $\mathrm{MM}$ in the Iranian population. However, compared to other populations, the abovementioned alleles had different statuses. There are other reports that show both consistency and inconsistency with our results. Ethnic variations among different populations in part explain these controversies. Further studies with large sample sizes or family studies are needed to confirm the exact associations of HLA genes with MM.

\section{Conflict of Interest Statement}

The authors of this paper have no conflicts of interest, including specific financial interests, relationships, and/or affiliations relevant to the subject matter or materials included. 
Table 2. The allele frequencies of HLA-A, -B, and -DRB1 in multiple myelom (MM) patient and control groups.

\begin{tabular}{|c|c|c|c|c|c|}
\hline Alleles & $\begin{array}{l}\text { MM patients, } \\
\text { n=210 [no. (\%)] }\end{array}$ & $\begin{array}{l}\text { Controls, } \\
\mathrm{n}=300 \\
{[\text { no. }(\%)]}\end{array}$ & p-value ${ }^{a}$ & pc-value & OR (95\% CI) \\
\hline HLA-A ${ }^{*} 01$ & $19(9)$ & $26(9)$ & 0.881 & NS & $1.048(0.564-1.948)$ \\
\hline HLA-A ${ }^{*} 02$ & $48(23)$ & $53(27)$ & 0.148 & NS & $1.381(0.891-2.140)$ \\
\hline HLA-A*03 & $46(21)$ & $36(12)$ & 0.003 & 0.039 & $2.057(1.276-3.316)$ \\
\hline HLA-A* 11 & $17(8)$ & $27(10)$ & 0.72 & NS & $0.891(0.472-1.679)$ \\
\hline HLA-A*23 & $8(4)$ & $10(3)$ & 0.032 & NS & $3.921(1.028-14.957)$ \\
\hline HLA-A*24 & $38(18)$ & $40(18)$ & 0.141 & NS & $1.436(0.885-2.330)$ \\
\hline HLA-A ${ }^{*} 26$ & $8(4)$ & $14(5)$ & 0.131 & NS & $2.337(0.754-7.245)$ \\
\hline HLA-A*29 & $4(2)$ & $2(1)$ & $0.235^{c}$ & NS & $2.893(0.525-15.943)$ \\
\hline HLA-A*30 & $4(2)$ & $10(3)$ & $0.454 c$ & NS & $1.922(0.426-8.680)$ \\
\hline HLA-A*31 & $13(6)$ & $12(5)$ & 0.259 & NS & $1.584(0.708-3.543)$ \\
\hline HLA-A*32 & $1(1)$ & $10(3)$ & $0.647 \mathrm{c}$ & NS & $0.474(0.049-4.585)$ \\
\hline HLA-A*33 & $2(1)$ & $5(2)$ & $0.705^{c}$ & NS & $0.567(0.109-2.952)$ \\
\hline HLA-A * 68 & $2(1)$ & $5(2)$ & $0.705^{c}$ & NS & $0.567(0.109-2.952)$ \\
\hline HLA-B ${ }^{*} 07$ & $11(5)$ & $18(6)$ & 0.715 & NS & $0.866(0.400-1.874)$ \\
\hline HLA-B*08 & $5(2)$ & $10(3)$ & $0.283^{c}$ & NS & $2.415(0.571-10.216)$ \\
\hline HLA-B*09 & $2(1)$ & $2(1)$ & $1.000^{c}$ & NS & $1.433(0.200-10.252)$ \\
\hline HLA-B* 13 & $4(2)$ & $12(4)$ & 0.182 & NS & $0.466(0.148-1.465)$ \\
\hline HLA-B* 14 & $0(0)$ & $3(1)$ & 0.272 & NS & - \\
\hline HLA-B* 15 & $2(1)$ & $3(1)$ & $1.000^{c}$ & NS & $0.952(0.158-5.747)$ \\
\hline HLA-B* 18 & $23(11)$ & $10(3)$ & 0.001 & 0.013 & $3.567(1.660-7.664)$ \\
\hline HLA-B*27 & $6(3)$ & $10(3)$ & 0.761 & NS & $0.853(0.305-2.384)$ \\
\hline HLA-B*35 & $52(25)$ & $84(28)$ & 0.416 & NS & $0.846(0.566-1.265)$ \\
\hline HLA-B*37 & $0(0)$ & $3(1)$ & $0.272^{c}$ & NS & $1.707(1.587-1.837)$ \\
\hline HLA-B*38 & $17(8)$ & $18(6)$ & 0.357 & NS & $1.380(0.694-2.745)$ \\
\hline HLA-B*39 & $6(3)$ & $4(1)$ & 0.222 & NS & $2.176(0.607-7.810)$ \\
\hline HLA-B* 40 & $6(3)$ & $6(2)$ & 0.530 & NS & $1.441(0.458-4.531)$ \\
\hline HLA-B*41 & $2(1)$ & $2(1)$ & $1.000^{c}$ & NS & $1.433(0.200-10.252)$ \\
\hline HLA-B*44 & $17(8)$ & $21(7)$ & 0.643 & NS & $1.170(0.602-2.276)$ \\
\hline HLA-B* 48 & $2(1)$ & $3(1)$ & $1.000^{c}$ & NS & $0.952(0.158-5.747)$ \\
\hline HLA-B*49 & $5(2)$ & $6(2)$ & 0.771 & NS & $1.195(0.360-3.969)$ \\
\hline HLA-B*50 & $2(1)$ & $7(2)$ & 0.244 & NS & $0.402(0.083-1.957)$ \\
\hline HLA-B*51 & (14) & $51(17)$ & 0.330 & NS & $0.782(0.477-1.283)$ \\
\hline HLA-B*52 & $6(3)$ & $7(2)$ & 0.712 & NS & $1.231(0.408-3.717)$ \\
\hline HLA-B*53 & $0(0)$ & $2(1)$ & 0.515 & NS & - \\
\hline
\end{tabular}




\begin{tabular}{|c|c|c|c|c|c|}
\hline HLA-B*54 & $0(0)$ & $3(1)$ & 0.272 & NS & - \\
\hline HLA-B*55 & $0(0)$ & $2(1)$ & 0.515 & NS & - \\
\hline HLA-B*56 & $0(0)$ & $3(1)$ & 0.272 & NS & - \\
\hline HLA-B $* 57$ & $5(2)$ & $5(2)$ & 0.567 & NS & $1.439(0.411-5.034)$ \\
\hline HLA-B*58 & $8(4)$ & $5(2)$ & 0.131 & NS & $2.337(0.754-7.245)$ \\
\hline HLA-DRB $1 * 01$ & $6(3)$ & $15(5)$ & 0.231 & NS & $0.559(0.213-1.465)$ \\
\hline HLA-DRB $1 * 03$ & $29(14)$ & $30(10)$ & 0.186 & NS & $1.442(0.837-2.484)$ \\
\hline HLA-DRB $1 * 04$ & $15(7)$ & $24(8)$ & 0.720 & NS & $0.885(0.452-1.730)$ \\
\hline HLA-DRB1 *07 & $8(4)$ & $12(4)$ & 0.913 & NS & $0.950(0.382-2.367)$ \\
\hline HLA-DRB $1{ }^{*} 08$ & $1(1)$ & $3(1)$ & $0.647 \mathrm{c}$ & NS & $0.474(0.049-4.585)$ \\
\hline HLA-DRB $1{ }^{*} 09$ & $5(2)$ & $3(1)$ & $0.217 \mathrm{c}$ & NS & $2.415(0.571-10.216)$ \\
\hline HLA-DRB1*10 & $11(5)$ & $12(4)$ & 0.507 & NS & $1.327(0.574-3.066)$ \\
\hline HLA-DRB1* 11 & $80(38)$ & $126(42)$ & 0.376 & NS & $0.850(0.592-1.219)$ \\
\hline HLA-DRB ${ }^{*} 12$ & $5(2)$ & $2(1)$ & 0.130 & NS & $3.634(0.698-18.912)$ \\
\hline HLA-DRB $1^{*} 13$ & $19(9)$ & $30(10)$ & 0.719 & NS & $0.895(0.489-1.638)$ \\
\hline HLA-DRB1*14 & $20(10)$ & $21(7)$ & 0.302 & NS & $1.398(0.738-2.651)$ \\
\hline HLA-DRB $1 * 15$ & $5(2)$ & $12(4)$ & 0.316 & NS & $0.585(0.203-1.687)$ \\
\hline HLA-DRB1* 16 & $6(3)$ & $10(3)$ & 0.761 & NS & $0.853(0.305-2.384)$ \\
\hline
\end{tabular}

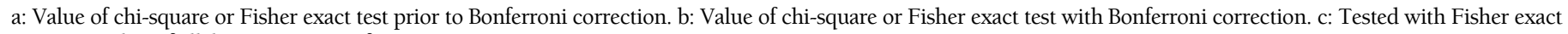
test. n: number of alleles. NS: not significant.

\section{References}

1. Kyle RA, Rajkumar SV. Criteria for diagnosis, staging, risk stratification and response assessment of multiple myeloma. Leukemia 2009;23:3-9.

2. Raab MS, Podar K, Breitkreutz I. Multiple myeloma. Lancet 2009;374:324-339

3. Collins CD. Problems monitoring response in multiple myeloma. Cancer Imaging 2005;5:119-126.

4. McPhedran P, Heath CW Jr, Garcia J. Multiple myeloma incidence in metropolitan Atlanta, Georgia: racial and seasonal variations. Blood 1972;39:866-873.

5. Blattner WA. Epidemiology of multiple myeloma and related plasma cell disorders: an analytic review. In: Potter M (ed.). Progress in Myeloma: Biology of Myeloma. New York, Elsevier/North Holland, 1980.

6. Cassuto JP, Piereschi J, Maiolini R, Dujardin P, Ribeil R, Masseyeff R. Marqueurs HLA dans les myélomes et les dysglobulinémies monoclonales bénignes. Nouv Presse Med 1981;10:252-253 (article in French).

7. Jeannet M, Magnin C. HL-A antigens in haematological malignant diseases. Eur J Clin Invest 1971;2:39-42.
8. Bertrams J, Kuwert E, Bohme U, Reis HE, Gallmeier WM, Wetter O, Schmidt CG. HL-A antigens in Hodgkin's disease and multiple myeloma. Tissue Antigens 1972;2:41-46.

9. Smith G, Walford RL, Fishkin B, Carter PK, Tanaka K. HLA phenotypes, immunoglobulins and $\mathrm{K}$ and $\mathrm{L}$ chains in multiple myeloma. Tissue Antigens 1974;4:374-377.

10. Mason DY, Cullen P. HL-A antigen frequencies in myeloma. Tissue Antigens 1975;5:238-245.

11. Van Camp BGK, Cole J, Peetermans ME. HLA antigens and homogeneous immunoglobulins. Clin Immunol Immunopathol 1977;7:315-318.

12. Saleun IP, Youinou P, Le Goff P, Le Menn G, Morin JF. HLA antigens and monoclonal gammapathy. Tissue Antigens 1979;13:233-235.

13. Pottern LM, Gart JJ, Nam J, Dunston G, Wilson J, Greenberg R. HLA and multiple myeloma among black and white men: evidence of a genetic association. Cancer Epidemiol Biomarkers Prev 1992;1:177-182.

14. Patel M, Wadee AA, Galpin J, Gavalakis C, Fourie AM, Kuschke RH, Philip V. HLA class I and class II antigens associated with multiple myeloma in southern Africa. Clin Lab Haematol 2002;24:215-219. 
15. Leech SH, Bryan CF, Elston RC, Rainey J, Bickers JN, Pelias MZ. Genetic studies in multiple myeloma. 1. Association with HLA-Cw5. Cancer 1983;51:1408-1411.

16. Miller SA, Dykes DD, Polesky HF. A simple salting out procedure for extracting DNA from human nucleated cells. Nucleic Acids Res 1998;16:1215.
17. Festen JJM, Marrink J, Sijpesteijn JAK, van Loghem E, Nijenhuis LE, Mandema E. A study on the association between myelomatosis and immunoglobulin allotypes, HLA, and blood groups. Immunogenetics 1976;3:201-203.

18. Ludwig H, Mayr W. Genetic aspects of susceptibility to multiple myeloma. Blood 1982;59:1286-1291. 